\title{
Effects of Safety Climate and Employee Engagement towards Organisational Citizenship Behaviour of Sewage Workers
}

\author{
Suryani Maryam, ${ }^{*}$ Ernie Tisnawati Sule, Joeliaty and \\ Rina Novianty Ariawaty
}

\begin{abstract}
Manuscript type: Research paper

Research aims: This study aims to investigate the effects of safety climate and employee engagement on organisational citizenship behaviour (OCB).

Design/Methodology/Approach: Drawing from the social exchange theory and flow theory, a theoretical framework was developed and tested using data collected from 610 freelance sewage workers. A questionnaire survey was used to collect the data, while structural equation modelling (SEM) analysis was used as the data analysis approach.

Research findings: The results reveal that both safety climate and employee engagement have significantly positive impact on employees' organisational citizenship behaviour amongst sewage workers in Indonesia. This finding indicates that although the sewage cleaners are often employed based on contract and may not be in a position to demand more from the organisations, they do appreciate the organisa-
\end{abstract}

\footnotetext{
* Corresponding author: Suryani Maryam is a Doctoral Scholar at the Faculty of Economics and Business, Universitas Padjadjaran, Indonesia. She is also attached to Universitas Pembangunan Nasional Veteran, Jakarta, Indonesia. Email: sunni_lubis@yahoo.com

Ernie Tisnawati Sule is a Professor at the Faculty of Economics and Business, Universitas Padjadjaran, Indonesia. Email: ernie.tisnawati@unpad.ac.id

Joeliaty is an Associate Professor at the Faculty of Economics and Business, Universitas Padjadjaran, Indonesia. Email: joeliaty@unpad.ac.id

Rina Novianti Ariawaty is a Lecturer at the Faculty of Economics and Business, Universitas Padjadjaran Indonesia. Email: rina.novianti@fe.unpad.ac.id

Acknowledgement: The authors would like to express gratitude to the Ministry of Finance, the Republic of Indonesia through Lembaga Pengelola Dana Pendidikan (LPDP) and Ministry of Research, Technology and Higher Education for providing the funds of this research.
} 
tional commitment in producing a safe workplace environment. They, in return will demonstrate a higher engagement towards their work.

Theoretical contribution/Originality: This study contributes to the organisational citizenship behaviour literature by examining how workplace environmental factors such as safety climate affects organisational citizenship behaviour. In the context of sewage cleaning, safety climate is important, as sewage workers are frequently exposed to and threatened by serious health problems. Yet, there has been a paucity of research on the sewage cleaning sector to understand the relationships.

Research limitation/Implications: The study implies that when organisations are willing to improve safety climate, their employees will perceive improved safety climate, and then will have more engagement and organisational citizenship behaviour.

Keywords: Safety Climate, Employee Engagement, Organisational Citizenship Behaviour, Sustainable Development Goals, Occupational Hazards

JEL Classification: M12, M54, M59, J28

\section{Introduction}

Managing human resources effectively is considered as a critical element that help organisations to boost employees' commitment and engagement towards their jobs, which would contribute to the organisational performance. Not only employees' satisfaction can be increased, but a good practice of human resource management may drive an organisational service levels, leading to high market demands (Aguiar-Quintana et al., 2020; Mustamil \& Najam, 2020). Thus, it is not surprising that understanding employee behaviour at the workplace has been a major concern in contemporary research on human resources. Organisational citizenship behaviour (OCB) has been an important area of study among scholars for the past two decades (e.g. Eisenberger et al., 2001; Gyekye \& Haybatollahi, 2015). According to Ozturk (2010), OCB is important to facilitate the achievement of organisational goals by improving employees' commitment and augmenting their organisational performance. OCB is defined as "individual behaviour that is discretionary, not directly or explicitly recognised by the formal reward system, and that in aggregate promotes the effective functioning of the organisation" (Organ, 1988, p. 4). It represents a set of positive behaviours by employees, which include volunteering for tasks that are unassigned, assisting subordinates with job-related assignments and providing 
any other work supports that are needed. Employees who engage in OCB are considered good citizens, as they help promote organisational effectiveness (Klotz et al., 2018). In short, employees who demonstrate high OCB will be more connected to workplace environment, and are ready to perform beyond their formal job descriptions (Naqshbandi et al., 2016; Randhawa \& Kaur, 2015).

Given the importance of OCB contributions towards organisational effective functioning, understanding the factors that drive OCB is thus imperative. Within the literature, studies have found that employees' active participation in OCB depends on the level of organisational support received (Kaur \& Randawa, 2021; Priyankara et al., 2018), organisational justice (Aguiar-Quintana et al., 2020; Khaola \& Rambe, 2020), interpersonal treatment (Rhoades \& Eisenberger, 2002), creative work climate, employee empowerment (Kasekende et al., 2016) and high-performance work systems (Singh et al., 2020). Furthermore, in several earlier meta-analytic studies (e.g. Podsakoff et al., 2009; Dalal 2005; Gyekye \& Salminen, 2008; Chu et al., 2005), OCB has been suggested to be related to employees' religiosity, job satisfaction and counterproductive behaviour. While extensive studies have been carried out on factors contributing to $\mathrm{OCB}$, there has been lack of attention to antecedents of OCB in the sewage cleaning sector. Studies on OCB have mainly concentrated on the hotel industry (Kasa \& Hasan, 2016), academic industry (Erturk, 2015), tourism sector (George \& Joseph, 2015) and manufacturing (Gyekye \& Haybatollahi, 2015; Singh et al., 2020). Motivated by the limitations identified in the previous studies, this study thus aims to empirically examine: (a) the relationship between safety climate and $\mathrm{OCB}$, and (b) the relationship between employee engagement and OCB amongst the sewage workers.

Many countries have neglected the degrading work of sewage cleaning, and their workers, who are commonly employed on a regular basis by state governments and local authorities. Sathyaseelan (2013) pointed out that sewage workers are more prone to accidents, and that they suffer from body aches, headache, irritation, watering, cut injuries, as well as tiredness and fatigue. They were also reported to have shorter lifespan due to being exposed to poisonous gases and toxic elements. In America, it was found that more than 60 per cent of sewage workers experience respiratory problems, which had been found to be linked to the company's productivity (Muzaini et al., 2021).

In a sector where employees are well-educated, receive good remuneration packages and have high job security, they are provided with 
quite good working conditions, where safety workplace environment may not be an issue. This situation however, may not be applicable in the context of sewage cleaning sector. While occupational safety and health $(\mathrm{OSH})$ has become one of the global sustainable development agenda, many of the sewage workers are hardly able to demand any kind of occupational safety measures from their employers. Their quality of work life is recorded to be lower as compared with the general workforce population due to the inbuilt nature of their working conditions and workplace environment (Uçan et al., 2020). In India, for instance, sewage workers enter manholes and septic tanks without being equipped by protective gears. Thus, health and quality of work life is dependent on the efforts of their employers to provide a safer work design. While socially responsible organisations are able to get employees involved in their jobs, and reciprocate by demonstrating OCB (Testa et al., 2020), this situation may not be found at the sewage cleaning industry, as the workers are on a contract basis and not entitled to get any benefits. Moreover, most of them have no choice, but to take this job, as they are not able to secure other jobs. Morrison (1994) also argued that employees may hold different views about their job responsibilities and may differ from each other while illustrating the boundary between what is in-role and extra-role behaviour. Thus, it is necessary to understand the relationship between safety work climate, employee engagement and OCB amongst sewage workers.

The remainder of the paper is as follows. Section 2 discusses the previous literature within the area and develops the hypotheses. Section 3 highlights the methodology that is employed in this study, while Section 4 reports the findings. The results and implications of the study are discussed in Section 5 and Section 6 respectively.

\section{Literature Review}

\subsection{Theoretical Underpinnings}

The theoretical framework of this study and hypotheses development are based on two theories which are: 1) social exchange theory, and 2) flow theory.

Social exchange theory - developed by Blau (1964) has been used widely within the workplace behaviour literature. It proposes that the interactions between two parties involve reciprocal interdependence, with an emphasis on maintaining the balance between giving and re- 
ceiving. Employees are argued to respond to their organisations with extra-role behaviours, beyond what are stipulated in the formal contract, when they obtain economic and socio-emotional resources in the workplace (Meira \& Hancer, 2021; Karatepe et al., 2018). Employees are expected to feel a high level of trust towards employers and be willing to work hard, as a means to repay for the rewards, respects, justice or any other supports provided to them. They are dedicated to the employer and feel obligated to contribute in achieving the organisation's goals, as they realise that their employer is dedicated to them (Jaiswal \& Dhar, 2016; Kurtessis et al., 2017).

Flow theory has its roots in research relating to personal causation and self-actualisation (Csikszentmihalyi, 1990). It is explained as a state of intense concentration and deep absorption in activities that contributes towards optimal working experiences (Lin \& Joe, 2012). An employee who is fully immersed in what he or she is doing, will develop a psychological feeling of vitality, and be fully engaged in work. It enables the employees to stretch their capabilities and skills to the limits, resulting in a sense of discovery and a strong motivation to achieve improved levels of working conditions (Bakker \& van Woerkom, 2017).

Within the sewage cleaning industry, little is known about the applicability of the social exchange theory and flow theory, thus creating an imperative need to understand the employee-organisation reciprocity behaviours, employee engagement and their positive outcomes in the industry. The following section discusses how the two theories are integrated in this study.

\subsection{Relationships between Safety Climate and Organisational Citizenship Behaviour}

Safety climate is defined as the "shared perceptions with regards to safety policies, procedures, and practices in an organisation" (Zohar, 2011, p. 143). One of the safety climate dimensions is management commitment to satisfy the occupational safety and health service needs of employees. The establishment of Sustainable Development Goals 2030 has presented a huge influence on organisations. Managements now have a larger role to play in enhancing the health and well-being of employees. They need to control any potential hazards present and provide a safe environment in the workplace. According to the literature, achievement of the highest standard of safety in the workplace environment is critical not only because it helps eliminate or minimise 
the health hazards and risks (Lawrence, 2010; Nzuve, 2012), but also because it is expected to increase OCB (Jiang \& Probst, 2015). This is because, when employees recognise the company's commitment in enhancing safety, through the improvement of the work environment and control of danger, the psychological attachment of employees to the organisation is expected to strengthen, resulting in a reduction in turnover intention, an increase in safety behaviour and citizenship behaviour. Employees respond accordingly to how they perceive they are treated by their organisation (Mearns et al., 2010).

The linkage between safety climate in an organisation and organisational citizenship behaviour is related to the fact that employee satisfaction comes from the meaningful organisational values, norms, beliefs, practices and procedures that operate in the workplace. If workers consider that their organisation supports and provides the structure of safety, they are more likely to feel satisfied. In addition, when the basic needs of employees are met consistently, they express job satisfaction and display greater emotional attachment and loyalty to their organisation (Lee et al., 2007). The importance of satisfying the occupational health and safety condition is especially important in a hazardous workplace environment, like the sewage cleaning sector. Based on these arguments, this study postulates that:

$\mathrm{H}_{1}$ : Safety climate is positively related to OCB.

\subsection{Relationships between Safety Climate and Employee Engagement}

Several studies have found a relationship between safety climate and aspects of employee engagement. For instance, Nahrgang et al. (2011) found that safety climate contributed to more variance in employee engagement than in other work resources examined in the study. In accordance with social exchange theory, the study reported that employees who had opportunities to work in a more positive safety climate assumed that the organisation cared about them and, as their safety needs were fulfilled, the employees were more satisfied with their jobs. In return, these satisfied employees would develop a sense of obligation towards their organisation to work harder, thus demonstrating higher levels of engagement. They feel that they have to reciprocate their positive experiences with a relatively active or directed state whereby they invest resources to accomplish their company's goal (i.e., higher level of engagement) and there are lower withdrawal rates (Jaiswal \& Dhar, 2016; Kurtessis et al., 2017). 
The management's commitment towards providing safety climate signals that the employers do not only fulfil the employee's implicit psychological contracts, but also care about employees (Nahrgang et al., 2011). In line with the social exchange theory, Dejoy et al. (2010) argued that employees tend to be more bound or committed to the organisation when they feel the organisation cares about their well-being. Committed employees tend to be more enthusiastic and motivated to perform well in their work, thereby producing a higher level of attachment or vitality at work. In another study, Kath et al. (2010) also explained that when positive relationships are damaged by negative perceptions of management's commitment to safety, employees tend to "pay back" the organisation by intending to leave the organisation. Based on these arguments, this study postulates that:

$\mathrm{H}_{2}$ : Safety climate is positively related to employee engagement.

\subsection{Relationships between Employee Engagement and Organisational Citizenship Behaviour}

The relationship between employee engagement and OCB can be explained by flow theory. Flow theory was proposed by Nakamura and Csikszentmihalyi (2001). They argued that a good life is characterised by being focused, fully engaged, and enjoying the process. In other words, the concept of flow describes the total absorption of what someone is doing. According to Csikszentmihalyi (1990), engagement can produce a condition called "flow"; one dimension of flow is intrinsic work motivation, which share an affinity with OCB dimensions, specifically the civic virtue dimension. Civic virtue is defined as behaviour that reveals that employees are in deep concentration, and have full interest in organisational life or work-related activities (Podsakoff et al., 2009).

Employees who have a sense of attachment to their work not only focus on their physical efforts on pursuing goals related to the role, but also are cognitively alert and emotionally connected to these efforts (Kahn, 1990). Conversely, employees who are very detached in their work roles hold their physical, cognitive, and emotional energy, and this is reflected best in their robotic, passive and separate task activities. Employees who are engaged will try harder to increase organisational performance, not only by improving their own performance, but also by focusing on the overall development of the organisation. Furthermore, employers who have more engaged employees within organisations 
that develop OCB, can also expand and maintain competitive advantage compared to other companies. Many studies have provided empirical evidence on the role of job engagement as a predictor for OCB (e.g. Sugianingrat et al., 2019; Rurkkhum \& Bartlett, 2012; Islam et al., 2012). Based on the arguments, this study postulates that:

$\mathrm{H}_{3}$ : Employee engagement is positively related to OCB.

Based on the previous literature and developed hypotheses, the following theoretical framework was formed:

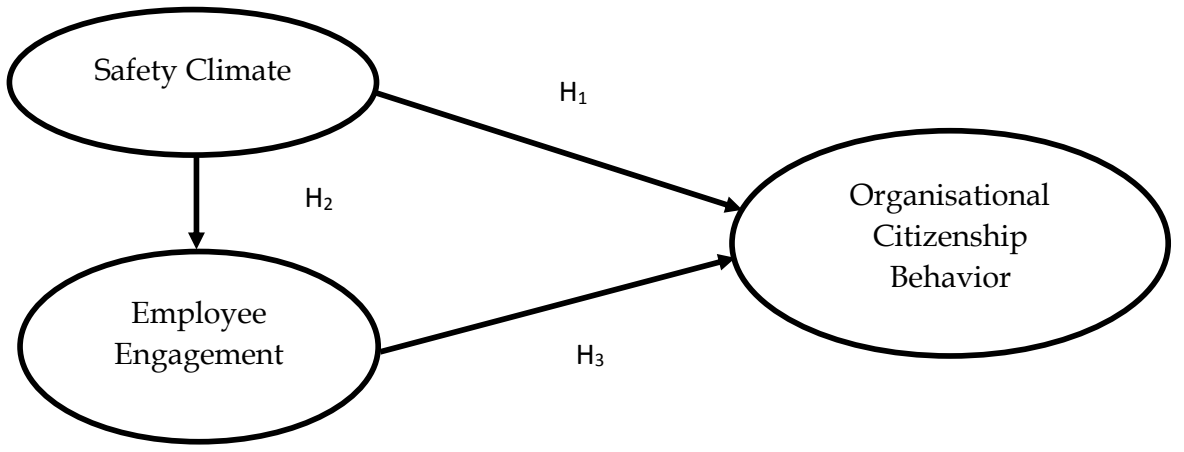

Figure 1: Research Framework

\section{Research Methodology}

This study employed a questionnaire survey to test the theoretical framework developed. Items used to measure the variables in the theoretical framework were adapted from previous literature, and were measured based on a six-point Likert scale ranging from 1 (never) to 6 (always).

The first variable, safety climate was measured by items adapted from Zohar (1980) and Lee et al. (2007). In total, twenty-five items which measure the extent of management commitment to safety and employees' involvement in individual as well as co-workers' safety were used. To measure the second variable, employee engagement, 20 items were adapted from Tiwari and Lenka (2016) and Soane et al. (2012). These items measure the extent of employee engagement according to the intellectual, social, affective, physical and organisational dimensions. The third variable, organisational citizenship behaviour, was measured by modifying several OCB measures, drawn from prior theoretical 
studies by Podsakoff et al. (2009) and Podsakoff and McKenzie (1994). Twenty-one items, which capture the extent of OCB demonstrated by the workers in terms of altruism, conscientiousness, civic virtue and courtesy were used. The samples of items in the questionnaire is provided in the Appendix. A double back to back translation was made on the questionnaire, where it was translated from English to the Indonesian language and then back to the English language. This process was performed since the daily language of the respondents is Indonesian and many did not understand the English language. The back to back translation was performed by two bilingual researchers so as to avoid language related errors. The researchers are native speakers of the Indonesian language with advanced knowledge of the English language.

Using stratified random sampling, a sample of 610 sewage workers who were employed by the government as freelance daily workers were selected. They were involved in removing garbage from the river. Prior to the data collection, permission to conduct the study was obtained from the management of the organisation.

The population of the workers of this study is 3,309. We distributed the questionnaire directly to 633 sewage workers. The size of sampling frame has fulfilled the minimum sample requirements suggested by Krejcie and Morgan (1970). The potential respondents were politely approached after they finished cleaning the river trash. The purpose of the study was highlighted clearly and the consent of the respondents to be a part of participants were obtained before the questionnaires were distributed. The researchers also emphasised that data collected were anonymous, confidential and individual responses would not be recognised. They were also assured that the data collected would be exclusively used for research purposes. Before they filled out the questionnaire, the participants were given an explanation on the statements contained in the questionnaire and the way to fill out the questionnaire. Of the 633 questionnaires, 23 questionnaires were discarded because there were statements in the questionnaire that were not filled out. Table 1 depicts the respondents' profiles.

A majority of the respondents were between the ages of 26 to 35 years old. More than half of them had attained at least the senior high school certificate $(51.6 \%)$. Males formed 99.5 per cent of the respondents, while females only contributed 0.5 per cent. This is expected due to the job characteristics of sewage cleaning, which is dirty and dangerous. 
Table 1: Respondents' Profiles

\begin{tabular}{llcc}
\hline Demographic Variable & Category & Frequency & Percentage (\%) \\
\hline Age & <25 years old & 95 & 15.6 \\
& 26-30 years old & 120 & 19.7 \\
& 31-35 years old & 108 & 17.7 \\
& 36-40 years old & 110 & 18.0 \\
& $>40$ years old & 177 & 29.0 \\
\hline Education & Elementary School & 122 & 20.0 \\
& Junior High School & 166 & 27.2 \\
& Senior High School & 315 & 51.6 \\
& Bachelor Degree & 7 & 1.1 \\
\hline \multirow{2}{*}{ Gender } & Female & 3 & 0.5 \\
& Male & 607 & 99.5 \\
\hline
\end{tabular}

\section{Results and Analysis}

Structural equation modelling using Lisrel 8.8 was utilised to analyse the data collected. We used a two-stage approach to minimise the changes to prevent any interaction between the structural and measurement models (Hair et al., 2010).

\subsection{Measurement Model Analysis}

The measurement model for each construct was independently checked for validity and reliability. Both convergent and discriminant validity were performed for this purpose (Churchill \& Iacobucci, 2010). In this study, convergent validity was determined by examining the factor loadings, average variance extracted (AVE) as well as composite reliability. As indicated in Table 2, the composite reliability and average variance extracted were greater than the threshold point of 0.7. The factor loadings of each item were between 0.78 and 0.96 . These values show that convergent validity exist in the dataset. In addition to convergent validity, the items were also tested for discriminant validity. In this study, discriminant validity was examined by comparing the square root of AVE values with the shared variance between contructs. Discriminant validity exists if the AVE values are above the correlations between the constructs (Fornell \& Lacker, 1981). As depicted in Table 3 , the AVE values were found to be higher than the correlation values 
Table 2: Results of Convergent Validity Test

\begin{tabular}{llccc}
\hline Variables & & $\begin{array}{c}\text { Factor } \\
\text { Loadings }\end{array}$ & $\begin{array}{c}\text { Composite } \\
\text { Reliability }\end{array}$ & $\begin{array}{c}\text { Average Variance } \\
\text { Extracted (AVE) }\end{array}$ \\
\hline Safety & Management commitment & $0.70-0.92$ & 0.98 & 0.79 \\
Climate & to safety & & & \\
& Employees' involvement & $0.86-0.91$ & & \\
& in individual safety & & & \\
& Employees' involvement & $0.84-0.93$ & & \\
& in co-workers safety & & & \\
Employees & Intellectual & $0.90-0.94$ & 0.98 & \\
Engagement & Social & $0.81-0.92$ & & 0.75 \\
& Affective & $0.87-0.96$ & & \\
& Physical & $0.84-0.96$ & & \\
\hline OCB & Organisational & $0.86-0.95$ & & \\
& Altruism & $0.78-0.90$ & 0.99 & \\
& Conscientiousness & $0.83-0.91$ & & \\
& Civic virtue & $0.83-0.91$ & & \\
& Courtesy & $0.68-0.81$ & & \\
\hline
\end{tabular}

Table 3: Discriminant Validity

\begin{tabular}{lccccc}
\hline Construct & Mean & SD & SC & EE & OCB \\
\hline Safety Climate (SC) & 3.64 & 1.16 & $\mathbf{0 . 8 7 2}$ & & \\
Employee Engagement (EE) & 3.74 & 1.09 & 0.751 & $\mathbf{0 . 9 0}$ & \\
Organisational Citizenship & 3.58 & 1.66 & 0.708 & 0.651 & $\mathbf{0 . 8 6 6}$ \\
$\quad$ Behaviour (OCB) & & & & & \\
\hline
\end{tabular}

Note: Bold diagonal values represent the square root of the AVE; the off-diagonal values represent the correlation coefficient; SD - standard deviation.

of between the respective constructs. This result demonstrates that the measurement model satisfies the discriminant validity.

\subsection{Structural Model and Hypothesis Testing}

Following the measurement validation through convergent and discriminant validity, this study performed structural analysis (Anderson \& Gebing, 1988). The model fit was assessed based on multiple fit 
indices, which include $p$-value for chi-square index, goodness-of-fit index (GFI), root mean square error of approximation (RMSEA), TuckerLewis index (TLI) and comparative fit index (CFI) and relative fit index (Schumacker \& Lomax, 2004). Table 4 summarises the goodness-of-fit index and hypotheses testing results. The analysis resulted in goodnessof-fit index of 0.912 , indicating that 99 per cent of the variances and covariances in the data observed were predicted by the estimated model. Moreover, results of fitting the structural model to the data revealed that the model had a good fit as indicated by the non normed fit index $(\mathrm{NNFI}=0.985)$, comparative fit index $(\mathrm{CFI}=0.988)$ root-mean-square error of approximation (RMSEA $=0.076$ ) and relative fit index (RFI = 0.982). Although the model's chi-square value was significant at the 0.05 significance level, the chi-square value is strongly affected by a sample size. If a sample size is large, the chi-square value is often significant. Instead of chi-square value, $\chi^{2}$ ratio and other fit indices may be more representative. Given the result of the structural model was used to test the hypotheses, the examination of the hypotheses was based on the $\mathrm{t}$-value. A value which is greater than 1.96 represents a significant path. As shown in Table 4, safety climate was found to be positively related with employee engagement $(\mathrm{t}$-value $=20.55, \beta=0.75)$ and OCB ( $\mathrm{t}$-value $=10.61, \beta=0.50)$, providing evidence to support $\mathrm{H}_{1}$ and $\mathrm{H}_{2}$. Employee engagement was also found to have a significant positive impact on OCB ( $\mathrm{t}$-value $=6.07, \beta=0.27$ ). Hence, $\mathrm{H}_{3}$ was also supported.

Table 4: Structural Model Analysis

\begin{tabular}{llccr}
\hline Hypotheses & Paths & t-Value & Coefficient & Results \\
\hline $\mathrm{H}_{1}$ & 1. $\mathrm{SC} \rightarrow \mathrm{EE}$ & 20.55 & $0.75^{* * *}$ & Supported \\
$\mathrm{H}_{2}$ & 2. $\mathrm{SC} \rightarrow \mathrm{OCB}$ & 10.61 & $0.50^{* * *}$ & Supported \\
$\mathrm{H}_{3}$ & 3. $\mathrm{EE} \rightarrow \mathrm{OCB}$ & 6.07 & $0.27^{* *}$ & Supported
\end{tabular}

GOFI: RMSEA $\left(\leq 0.08^{* *}\right)=0.076$; NNFI $\left(\geq 0.90^{* *}\right)=0.985$; CFI $\left(\geq 0.90^{* *}\right)=0.98$; IFI $\left(\geq 0.90^{* *}\right)=0.98$; RFI $\left(\geq 0.90^{* *}\right)=0.98$; SRMR $\left(\leq 0.05^{* *}\right)=0.03$; GFI $\left(\geq 0.90^{* *}\right)=0.91$; Norm $\chi 2(\leq 2)=0.00$

Note: ** - p-value <0.05, *** p-value<0.001, SC - safety climate, EE - employee engagement, OCB - organisational citizenship behaviour. 
Effects of Safety Climate and Employee Engagement towards Behaviour of Sewage Workers

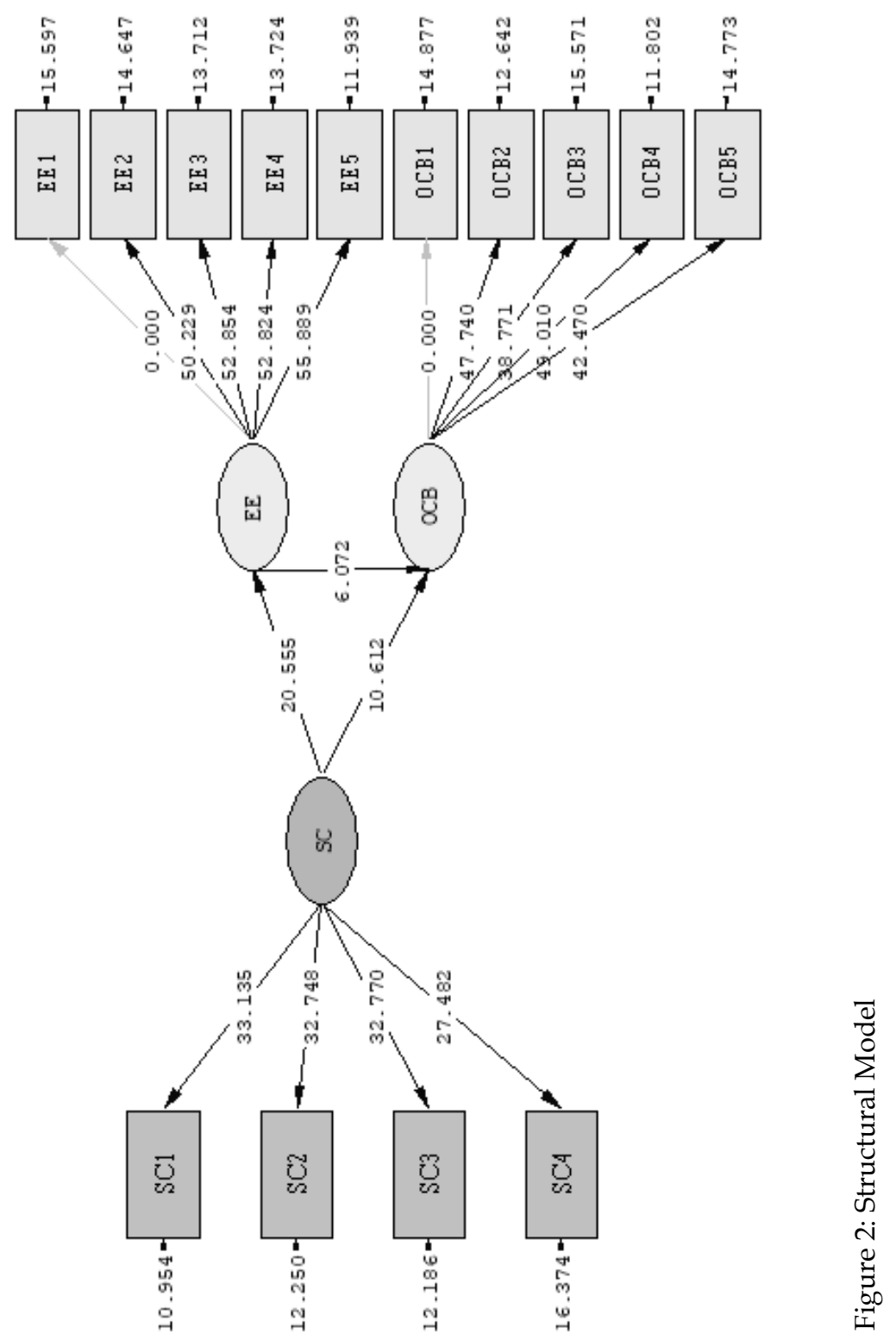




\section{Discussion}

Drawn from the social exchange theory and flow theory, this study has investigated the impact of safety climate and employee engagement on OCB amongst sewage workers. The findings demonstrate that a safety climate serves as a crucial factor that promotes OCB and employee engagement. This finding is in line with prior studies (Jiang \& Probst, 2015; Lambert et al., 2008). Management commitment to safety appears to generate a higher level of employee engagement and OCB amongst the sewage cleaners. The results highlight that although the sewage cleaners are often employed based on contract and may not be in a position to demand more from the organisations, they do appreciate the organisational commitment in producing a safe workplace environment, and in return will demonstrate a higher engagement. Perhaps, the work environment which expose the sewage cleaners to various hazards such as chemicals and reagents, infectious wastewater stream and slip (Muzaini et al., 2021) contribute to a higher appreciation of safety climate amongst them. In a high-risk organisation such as this, workers may perceive safety climate as an important driver which can motivate them to support the functioning of the organisation positively in various ways, including engaging in OCB (Lu et al., 2017). Since their work is considered as hazardous occupations, they depend greatly on their management to keep them safe. The more employees perceive the management's support in providing a safer workplace environment, the more likely they will feel obligated to reciprocate by demonstrating positive job attitudes and behaviour. This findings also imply that safety workplace climate is not a priority of big firms or employees with higher pay, but it is a demand for majority of societies as a basic human right. In fact, the responsibility should not only be carried out by safety units, but also the entire organisation.

Another possible reason for the significant relationships between the variables, could be due to the fact that 99.5 per cent of the respondents in this study were males. Past studies have showed that gender has an impact on certain work behaviour. In a meta-analytic study, Peshkovskaya et al. (2019) found that men are more cooperative than women in same-sex groups and become more cooperative over repeated iterations of a dilemma with the same partner. Eagly (2009) argued that men are more likely to engage in chivalrous or heroic acts of helping that require physical strength than are women. Assertiveness and performance are seen as indicators of greater agency in men, 
and warmth and care for others are viewed as signs of greater communality in women. Moreover, masculine behaviours are typically more aggressive and independent than feminine behaviour (Spence \& Helmreich, 1978). It was found that helping behaviours (OCB-I) were more consistent with participants' schema for women, whereas civic virtue behaviours (OCB-O) were more consistent with participants' schema for men. Chiaburu et al. (2014) found that by activating gender stereotypes, more civic virtue are expected from male employees than from female employees. Thus, the OCB dimensions may be divided by gender roles. In the case of this study, civic virtue may be regarded as more in-role for men (Spence \& Helmreich, 1978).

This study also found that there is a significant relationship between employee engagement and organisational citizenship behaviour. The results indicate that the sewage workers who have a sense of attachment to the company will give extra effort to increase organisational performance, not only by improving their own performance, but also by focusing on the overall development of the organisation. This finding is consistent with Rurkkhum and Bartlett (2012) and Kataria et al. (2012). This study provides evidence that by controlling hazardous environment and providing appropriate physical working conditions, the level of employees' commitment and motivation to increase the throughput is much higher.

\section{Conclusion and Implications}

The results of this study contribute to the organisational citizenship behaviour literature. It expands the existing literature by providing empirical evidence on the importance of safety climate and employee engagement towards OCB in the sewage cleaning sector. Despite the importance of a safe workplace environment in the sewage cleaning sector, little study has been attempted to investigate how this would affect OCB. While achieving sustainable development goals is dependent on the health, safety and well-being of a working population, the basic occupational health facilities in developing countries is poor and receives a lack of attention. This study thus presents some insights into how safety climate could lead to positive organisational outcomes.

Practically, the findings suggest that organisations need to demonstrate a higher commitment in providing a safe workplace environment for workers who are involved in a high-risk environment, such as 
sewage cleaners. Although they are commonly employed on a contract basis, and are not entitled to any benefits, it appears that satisfying their safety needs in relation to work demands could contribute to positive organisational outcomes. Thus, it is imperative to indicate that management commitment to employee safety, employee involvement, safety support from colleagues, proper monitoring and supervision will improve organisational citizenship behaviour. Engagement occurs naturally when organisations provide a safe work environment, conducive to well-being. Therefore, the organisation should engage in attitudes and behaviours that promote a safe workplace, conducive to the well-being of its workers. Furthermore, organisations need to ensure that employees working in their organisations are engaged in their job, because when employees are engaged, they are willing to put in extra effort. Organisations also need to identify whether their employees have a sense of engagement and investigate the reasons for disengagement, if any, and then take steps to overcome the drawbacks.

\section{References}

Aguiar-Quintana, T., Araujo-Cabrera, Y., \& Park, S. (2020). The sequential relationships of hotel employees' perceived justice, commitment, and organisational citizenship behaviour in a high unemployment context. Tourism Management Perspectives, 35, Article 100676. https://doi.org/ 10.1016/j.tmp.2020.100676

Anderson, J.C., \& Gerbing, D.W. (1988). Structural equation modeling in practice: A review and recommended two-step approach. Psychological Bulletin, 103(3), 411-423.

Bakker, A.B., \& van Woerkom, M. (2017). Flow at work: A self-determination perspective. Occupational Health Science, 1(1), 47-65. https://doi.org/ $10.1007 / \mathrm{s} 41542-017-0003-3$

Blau, P.M. (1964). Social exchange theory. Wiley.

Chiaburu, D.S., Thundiyil, T.G., \& Wang, J. (2014). Alienation and its correlates: A meta-analysis. European Management Journal, 32(1), 24-36. https://doi. org/10.1016/j.emj.2013.06.003

Chu, C.I., Lee, M.S., Hsu, H.M., \& Chen, I.C. (2005). Clarification of the antecedents of hospital nurse organisational citizenship behavior - an example from a Taiwan regional hospital. Journal of Nursing Research, 13(4), 313-324. https:/ / doi.org/10.1097/00134372-200512000-00009

Churchill, G.A., \& Iacobucci, D. (2002). Marketing research: Methodological foundations (10th ed.). South-Western Cengage Learning.

Csikszentmihalyi, M. (1990). Flow: The psychological optimal experience. Harper \& Row. 
Dalal, R.S. (2005). A meta-analysis of the relationship between organisational citizenship behavior and counterproductive work behavior. Journal of Applied Psychology, 90(6), 1241-1255. https://doi.org/10.1037/0021-9010. 90.6.1241

DeJoy, D.M., Della, L.J., Vandenberg, R.J., \& Wilson, M.G. (2010). Making work safer: Testing a model of social exchange and safety management. Journal of Safety Research, 41(2), 163-171. https:/ / doi.org/10.1016/j.jsr.2010.02.001

Eagly, A.H. (2009). The his and hers of prosocial behavior: An examination of the social psychology of gender. American Psychologist, 64(8), 644-658. https://doi.org/10.1037/0003-066X.64.8.644

Eisenberger, R., Armeli, S., Rexwinkel, B., Lynch, P.D., \& Rhoades, L. (2001). Reciprocation of perceived organisational support. Journal of Applied Psychology, 86(1), 42-51. https://doi.org/10.1037/0021-9010.86.1.42

Erturk, A. (2015). Organisational citizenship and mobbing behavior of secondary school teachers. The Anthropologist, 22(1), 113-124. https://doi.org/10.1080 /09720073.2015.11891862

Fornell, C., \& Larcker, D.F. (1981). Evaluating structural equation models with unobservable variables and measurement error. Journal of Marketing Research, 18(1), 39-50. https:/ / doi.org/10.2307/3151312

George, G., \& Joseph, B. (2015). A study on the relationship between employee engagement and organisational citizenship with reference to employees working in travel organisations. Atna Journal of Tourism Studies, 10(2), 3344. https:// doi.org/10.12727/ajts.14.3

Gyekye, S.A., \& Haybatollahi, M. (2015). Organizational citizenship behaviour: An empirical investigation of the impact of age and job satisfaction on Ghanaian industrial workers. International Journal of Organizational Analysis, 23(2), 285-301. https://doi.org/10.1108/ijoa-08-2012-0586

Gyekye, S.A., \& Salminen, S. (2008). Are good citizens religious? Exploring the link between organisational citizenship behaviours and religious beliefs. Journal for the Study of Religion, 21(2), 85-98. https://doi.org/10.4314/jsr. v21i2.65747

Hair, J.F., Black, W.C., Babin, B.J., \& Anderson, R.E. (2010). Multivariate data analysis (7th ed.). Pearson Education.

Islam,T., Khan, S.U.R., Aamir, M., Ahmed, I., Ahmad, U.N.K.U, \& Shaukat, M.Z. (2012). Moderating role of HRD practices between employees' engagement and citizenship behaviours. Middle-East Journal of Scientific Research, 12(5), 589-597.

Jaiswal, D., \& Dhar, R.L. (2016). Impact of perceived organisational support, psychological empowerment and leader member exchange on commitment and its subsequent impact on service quality. International Journal of Productivity and Performance Management, 65(1), 58-79. https://doi.org/ 10.1108/ijppm-03-2014-0043

Jiang, L., \& Probst, T.M. (2015). The relationship between safety-production conflict and employee safety outcomes: Testing the impact of multiple 
organisational climates. Work $\mathcal{E}$ Stress, 29(2), 171-189. https:// doi.org/10.1 080/02678373.2015.1032384

Kahn, W.A. (1990). Psychological conditions of personal engagement and disengagement at work. Academy of Management Journal, 33(4), 692-724. https://doi.org/10.5465/256287

Karatepe, O.M., Yavas, U., Babakus, E., \& Deitz, G.D. (2018). The effects of organizational and personal resources on stress, engagement, and job outcomes. International Journal of Hospitality Management, 74, 147-161. https://doi.org/10.1016/j.ijhm.2018.04.005

Kasa, M., \& Hassan, Z. (2016). Flow experience and organizational citizenship behaviour among hotel employees: Moderating effect of socio-cultural factor. Procedia - Social and Behavioral Sciences, 224, 101-108. https://doi. org/10.1016/j.sbspro.2016.05.409

Kasekende, F., Munene, J.C., Otengei, S.O., \& Ntayi, J.M (2016). Linking teacher competences to organizational citizenship behaviour: The role of empowerment. International Journal of Educational Management, 30(2), 252270. https://doi.org/10.1108/ijem-10-2014-0140

Kataria, A., Garg, P., \& Rastogi, R. (2012). Employee engagement and organizational effectiveness: The role of organizational citizenship behavior. International Journal of Business Insights \& Transformation, 6(1), 102-113.

Kath, L.M., Magley, V.J., \& Marmet, M. (2010). The role of organisational trust in safety climate's influence on organisational outcomes. Accident Analysis $\mathcal{E}$ Prevention, 42(5), 1488-1497. https:// doi.org/10.1016/j.aap.2009.11.010

Kaur, D.K., \& Randhawa, D.G. (2021). Exploring the influence of supportive supervisors on organisational citizenship behaviour: Linking theory to practice. IIMB Management Review. Advance online publication. https:// doi.org/10.1016/j.iimb.2021.03.012

Khaola, P., \& Rambe, P. (2020). The effects of transformational leadership on organisational citizenship behaviour: The role of organisational justice and affective commitment. Management Research Review, 44(3), 381-398. https:// doi.org/10.1108/mrr-07-2019-0323

Klotz, A.C., Bolino, M.C., Song, H., \& Stornelli, J. (2018). Examining the nature, causes, and consequences of profiles of organizational citizenship behavior. Journal of Organizational Behavoir, 39(5), 629-647. https://doi.org/10.1002/ job.2259

Krejcie, R.V., \& Morgan, D.W. (1970). Determining sample size for research activities. Educational and Psychological Measurement, 30(3), 607-610. https:// doi.org/10.1177/001316447003000308

Kurtessis, J.N., Eisenberger, R., Ford, M.T., Buffardi, L.C., Stewart, K.A., \& Adis, C.S. (2017). Perceived organisational support: A meta-analytic evaluation of organisational support theory. Journal of Management, 43(6), 1854-1884. https://doi.org/10.1177/0149206315575554

Lambert, E.G., Hogan, N.L., \& Griffin, M.L. (2008). Being the good soldier: Organizational citizenship behavior and commitment among correctional 
staff. Criminal Justice and Behavior, 35(1), 56-68. https://doi.org/10.1177/ 0093854807308853

Lee, T.Z., Wu, C.H., \& Hong, C.W. (2007). An empirical investigation of the influence of safety climate on organisational citizenship behavior in Taiwan's facilities. International Journal of Occupational Safety and Ergonomics, 13(3), 255-269. https://doi.org/10.1080/10803548.2007.11076726

Lin, C.P., \& Joe, S.W. (2012). To share or not to share: Assessing knowledge sharing, interemployee helping, and their antecedents among online knowledge workers. Journal of Business Ethics, 108, 439-449. https://doi. org/10.1007/s10551-011-1100-x

Lu, C.S., Weng, H.K., \& Lee, C.W. (2017). Leader-member exchange, safety climate and employees' safety organizational citizenship behaviors in container terminal operators. Maritime Business Review, 2(4), 331-348. https:/ / doi.org/10.1108/mabr-11-2017-0028

Mearns, K., Hope, L., Ford, M.T., \& Tetrick, L.E. (2010). Investment in workforce health: Exploring the implications for workforce safety climate and commitment. Accident Analysis \& Prevention, 42(5), 1445-1454. https://doi. org/10.1016/j.aap.2009.08.009

Meira, J.V., \& Hancer, M. (2021). Using the social exchange theory to explore the employee-organization relationship in the hospitality industry. International Journal of Contemporary Hospitality Management, 33(2), 670-692. https://doi. org/10.1108/ijchm-06-2020-0538

Morrison, E.W. (1994). Role definitions and organisational citizenship behavior: The importance of the employee's perspective. Academy of Management Journal, 37(6), 1543-1567. https:/ / doi.org/10.2307/256798

Mustamil, N., \& Najam, U. (2020). The impact of servant leadership on follower turnover intentions: Mediating role of resilience. Asian Journal of Business and Accounting, 13(2), 125-146. https://doi.org/10.22452/ajba.vol13no2.5

Muzaini, K., Yasin, S.M., Ismail, Z., \& Ishak, A.R. (2021). Systematic review of potential occupational respiratory hazards exposure among sewage workers. Frontiers in Public Health, 9, Article 646790. https://doi. org/10.3389/fpubh.2021.646790

Nahrgang, J.D., Morgeson, F.P., \& Hofmann, D.A. (2011). Safety at work: A meta-analytic investigation of the link between job demands, job resources, burnout, engagement, and safety outcomes. Journal of Applied Psychology, 96(1), 71-94. https:/ / doi.org/10.1037/a0021484

Nakamura, J., \& Csikszentmihalyi, M. (2001). Catalytic creativity: The case of Linus Pauling. American Psychologist, 56(4), 337-341. https://doi.org/ 10.1037/0003-066X.56.4.337

Naqshbandi, M.M., Garib Singh, S.K., \& Ma, P. (2016). The link between organisational citizenship behaviours and open innovation: A case of Malaysian high-tech sector. IIMB Management Review, 28(4), 200-211. https://doi.org/10.1016/j.iimb.2016.08.008 
Nzuve, M., \& Ayubu, B. (2012). The extent of compliance with occupational safety and health regulations at registered workplaces in Nairobi. International Journal of Business, Humanities and Technology, 2(2), 115-119.

Organ, D.W. (1988). Organisational citizenship behavior, the good soldier syndrome. Lexington Books.

Ozturk, F. (2010). Determinants of organisational citizenship behavior among knowledge workers: The role of job charcteristics, job satisfaction, and organizational commitment (Doctoral dissertation, Marmara University, İstanbul). https:// etd.lib.metu.edu.tr/upload/12612296/index.pdf

Peshkovskaya, A., Babkina, T., \& Myagkov, M. (2019). Gender effects and cooperation in collective action: A laboratory experiment. Rationality and Society, 31(3), 337-353. https:// doi.org/10.1177/1043463119858788

Podsakoff, P.M., \& MacKenzie, S.B. (1994). Organisational citizenship behaviour and sales unit effectiveness. Journal of Marketing Research, 31(3), 351-363. https://doi.org/10.1177\%2F002224379403100303

Podsakoff, N.P., Whiting, S.W., Podsakoff, P.M., \& Blume, B.D. (2009). Individualand organisational-level consequences of organisational citizenship behaviors: A meta-analysis. Journal of Applied Psychology, 94(1), 122-141. https:// psycnet.apa.org/doi/10.1037/a0013079

Priyankara, H., Luo, F., Saeed, A., Nubuor, S., \& Jayasuriya, M. (2018). How does leader's support for environment promote organizational citizenship behaviour for environment? A multi-theory perspective. Sustainability 10, 271-291. https:// doi.org/10.3390/su10010271

Randhawa, G., \& Kaur, K. (2015). An empirical assessment of impact of organisational climate on organisational citizenship behaviour. Paradigm, 19(1), 65-78. https:// doi.org/10.1177/0971890715585202

Rhoades, L., \& Eisenberger, R. (2002). Perceived organisational support: A review of the literature. Journal of Applied Psychology, 87(4), 698-714. https:// doi.org/10.1037/0021-9010.87.4.69

Rurkkhum, S., \& Bartlett, K.R. (2012). The relationship between employee engagement and organisational citizenship behaviour in Thailand. Human Resource Development International, 15(2), 157-174. https:// doi.org/10.1080/ 13678868.2012.664693

Sathyaseelan, S. (2013). Neglect of sewage workers: Concerns about the new act. Economic and Political Weekly, 48(49), 33-37.

Schumacker, R.E., \& Lomax R.G. (2004). A beginner's guide to structural equation modeling. Psychological Press.

Singh, J.P., Chand, P.K., Mittal, A., \& Aggarwal, A. (2020). High-performance work system and organisational citizenship behaviour at the shop floor. Benchmarking: An International Journal, 27(4), 1369-1398. http://doi.org/ 10.1108/ bij-07-2019-0339

Soane, E., Truss, C., Alfes, K., Shantz, A., Rees, C., \& Gatenby, M. (2012). Development and application of a new measure of employee engagement: The 
ISA engagement scale. Human Resource Development International, 15(5), 529-547. https://doi.org/10.1080/13678868.2012.726542

Spence, J.T., \& Helmreich, R.L. (1978) Masculinity \& femininity: Their psychological dimensions, correlates, $\mathcal{E}$ antecedents. University of Texas Press.

Sugianingrat, I.A.P.W., Widyawati, S.R., da Costa, C.A.D.J., Ximenes, M., Piedade, S.D.R., \& Sarmawa, W.G. (2019). The employee engagement and $\mathrm{OCB}$ as mediating on employee performance. International Journal of Productivity and Performance Management, 68(2), 319-339. https://doi. org/10.1108/IJPPM-03-2018-0124

Testa, F., Todaro, N., Gusmerotti, N.M., \& Frey, M. (2020). Embedding corporate sustainability: An empirical analysis of the antecedents of organization citizenship behavior. Corporate Social Responsibility and Environmental Management, 27(3), 1198-1212. https:// doi.org/10.1002/csr.1875

Tiwari, B., \& Lenka, U. (2016). Building psychological safety for employee engagement in post-recession. Development and Learning in Organisations, 30(1), 19-22. https:// doi.org/10.1108/DLO-05-2015-0044

Uçan, R., Şanlıer, H., \& Özay, M.E. (2020). Investigation of job satisfaction and occupational safety perceptions of employees in wastewater treatment plants: Study of Istanbul. International Journal of Occupational Safety and Health, 10(1), 3-10. http://doi.org/10.3126/ijosh.v10i1.29876

Zohar, D. (1980). Safety climate in industrial organizations: Theoretical and applied implications. Journal of Applied Psychology 65(1), 96-102. https:// doi.org/10.1037/0021-9010.65.1.96

Zohar, D. (2011). Safety climate: Conceptual and measurement issues. In J.C. Quick \& L.E. Tetrick (Eds.), Handbook of occupational health psychology (pp. 141-164). American Psychological Association. 


\section{Appendix}

\section{Sample of Items Used in the Questionnaire}

I would be happy to work at my organisation until I retire

Working at my organisation has a great deal of personal meaning to me I really feel that problems faced by my organisation are also my problems I feel personally attached to my work organisation I am proud to tell others I work at my organisation I feel a strong sense of belonging to my organisation Performing my job is so absorbing that I forget about everything else I am rarely distracted when performing my job

\section{Emotional engagement}

I really put my heart into my job

I often feel emotionally detached from my job

\section{Physical engagement}

I exert a lot of energy performing my job

I stay until the job is done

Intellectual engagement I focus hard on my work

I concentrate on my work

I pay a lot of attention to my work

\section{Social engagement}

I share the same work values as my colleagues

I share the same work goals as my colleagues

I share the same work attitudes as my colleagues

\section{Affective engagement}

I feel positive about my work

I feel energetic in my work

I am enthusiastic in my work

I am happy to help in promoting my company's reputation

I am happy to attend any meeting in my company

I actively help my company find problems

I actively bring up suggestions for my company

I collaborate with my coworkers in accomplishing tasks

I pay a lot of attention to my behavior that is important to my company

I actively understand company's decisions

I help coworkers who are overworked

I actively help my supervisor in his/her job

I am willing to listen to my coworkers' problems 
I am willing to provide my coworkers with information they need I always finish my work on time

I work hard in my job

I am willing to attend activities that are directly related to my performance

I always fulfill my job description

I always complete my duties

I have always been successful in my job

I always reach the goal that I expect in my job 
